\title{
Strategy of Cooperative Islamic Boarding School as Economic Empowerment Community
}

\author{
Adhi Iman Sulaiman, Chusmeru, Masrukin \\ Jenderal Soedirman University \\ adhi.2005unsoed@gmail.com,chusmeru@yahoo.com,pak_masrukin@yahoo.co.id
}

\begin{abstract}
The development of Islamic boarding school (Pesantren) that is no longer just to teach religion, but has become a social and economic institution with delivers the knowledge and skills of cooperative and entrepreneurship in Pesantrens. The study used qualitative method through Participatory Learning and Action (PLA). Research location in one of the largest Pesantren namely El Bayan 1 and 2, Cilacap, Cetral Java. The study determined the informant through purposive sampling i.e. the managers and members of cooperative Pesantren. Data were collected by interviews, focus group discussion, observation and documentation. Research data were analyzed with the SWOT analysis. The results showed the strategy cooperative Pesantrens in the economic empowerment of students is very important with the to improve and enhance institutional managed, membership, finance, partnerships and the development of agribusiness based business unit to enhance the well-being of Pesantren, student and the community.
\end{abstract}

Keywords: Cooperative, Economic empowerment, Entrepreneurship, Boarding school.

\begin{abstract}
Abstrak
Pernkembanganpondokpesantrenpadasaatini, tidakhanyamengajarkanpendidikan agama, tetapi telab menjadi lembaga sosial dan ekonomi dengan memberikan pengetahuan dan keterampilan koperasi dan kewirausahaan di pesantren. Penelitian ini menggunakan metode kualitiaif melalui Participatory Learning and Action (PLA). Lokasi penelitian di salah satu pesantren terbesar di Cilacap Jawa Tengah yaitu El Bayan 1 dan 2. Pemilihan informan melalui purposif sampling yaitu pengurus dan anggota koperasi pondok pesantren. Pengumpulan data dengani wawancara, focus group discussion, observasi dan dokumentasi. Analisis data penelitian menggunakan analisis SWOT. Hasil penelitian menunjukkan strategi koperasi pesantren dalam pemberdayaan ekonomi Santri sangat penting untuk meningkatkan pengelolaan kelembagaan, keanggotaan, keuangan, kerjasama dan pengembangan agribisnis dalam kelompok usaha untuk meningkatkan kesejabteraan bagi pesantren, Santri dan masyarakat.
\end{abstract}

Kata kunci: Koperasi, Pemberdayaan ekonomi, Kewirausahaan, Pesantren.

Permalink/DOI: http://dx.doi.org/10.18326/infs13v12i1.25-44 


\section{Introduction}

Islamic boarding school (Pesantren) as institutions of Islam have long existed and functioned in the community in the field of religious education informally, on the next stage development of Pesantrens respond changes and challenges of the times into a modern Pesantren with complete of the role as formal educational institutions, social and economic institutions. According to Rizal (2011) Pesantren is the oldest in Indonesia education systems that existed from local wisdom and be able to adopt the changes without leave the principles and purposes of the religious (Islam) as charms and characteristics. Syamsi (2013) Pesantren that has traditional thinking tends to maintain the curriculum and the education system is hereditary which is difficult to change and dogmatic against religious teachings, while modernist thinking has tended to do updates for implementation education at Pesantren by studying the fields other than religious. Tan (2014) many Islamic schools in Indonesia face a perennial challenge in infusing Islamic principles and values into the teaching of modern 'secular' subjects. Stewart (2015) the transition from remote indigenous community to Pesantren that indigenous students to quality education provision in major urban centres is a key element of government policy in addressing disadvantage in education outcomes between Indigenous and non-Indigenous students.

Pesantren as Islamic institutions can be strengthened aspects of academic or non-academic, but retaining the reinforcement value of religiosity and the tradition of Pesantren while simultaneously innovating to be able to respond to changes in society. The changes of education in a Pesantren that unites religiosity with social and economy in providing the knowledge, skills and self-sufficiency to enhance the well-being of Pesantrens and students. It can anticipate a negative stigma against Pesantren which was rated as an ancient religious institutions, covered and difficult to accept change. Hidayat (1998) religious radicalism at Pesantren symptoms are psychological-sociological caused politics and religion is disputed, as well as discriminatory treatment and feelings of injustice. 
According to g to Yuli et al. (2011) Islamic Pesantrens that is able to accommodate the time and to eliminate the incidence of deviant behavior of the students who are educated within and the anticipation to the radical movements implicated in the lodge. According to Ahyar (2015) the negative stigma towards Islamic Pesantren and become a legitimate identity do not bring progress of development. Islam is seen as the only source and supporting terrorists who don't value pluralism and cannot bring prosperity and equality.

Based on the foregoing, the study of the dynamics of the Pesantren into a very interesting and important especially role of Pesantren as religious institutions, social and economic in improving welfare Pesantren as well as Islamic student (Santri), because it has experience and expertise in the economy or entrepreneurship. So the Santri after graduation from Pesantrens can play a role in the development process of both mental and spiritual, moral, social and economic progress brings in people's lives. The religious education, social and Economics at Pesantren is very relevant to the concept of Islam carry out a balance between the life of the world and the hereafter as well as a mercy for all of the world (Rabmatan Lil'aalamiin). According to Hadi (1997) Pesantrens can be an agency for human resource development, information center, education, agribusiness and financial institutions to serve the public. Susila (2014) cooperative Pesantren can improve the welfare of the Muslims both Santri as well as the community. Sulaiman et al. (2016) Pesantrens have a role that is as strategically important institutions that forming character and behaviour of the religious, moral and spiritual, as well as social and economic education as well as entrepreneurship in cooperative Pesantrens. The cooperative of Pesantren as community development to advance the economic effort based on the potential of the Santri as well as society and togetherness in improving well-being and self-reliance.

The potential of human Resources to become the economy of sustainability, working towards more sustainable community 
development (Sahakian and Dunand 2014). Community organizing refers to a particular way of working in public life that aims to enhance the capacity of community leaders to act for the common good in collaboration across civil society (Tattersall 2015).

Essentially, development should be the common property of civil society and government in empowering the potential range of community resources for the welfare of rural communities including Pesantren society as community development. Rural development becomes very important, strategic and decisive in improving wellbeing. According to Adi (2013) development in Indonesia will have less meaning if it is not done in rural communities, because it should be realized that still quite a lot of villages are not yet developed. Therefore, there needs to be a comprehensive study and research to provide the best solution for rural development with a more participative approach, where all the elements get involved and cooperate to determine or achieve a common goal.

\section{Research Methods}

Authors interested to study of cooperative Pesantrens in the economic empowerment of Santri as a result of research carried out in the year 2017 and 2018 at Pesantrens af El Bayan 1 and El Bayan 2 in Majenang sub-district. The Pesantren of El Bayan was chosen as the research location, because El Bayan as one of the largest Pesantren in District of Cilacap, Central Java Province has existed and functioned for a long time and have cooperative Pesantrens.

Research used qualitative methods of Participatory Learning and Action (PLA) to identify potential problems, and a deep understanding of the situation of a community as a community worker to analyze and make decisions from the problems faced as a process of assessment, learning, optimize the aspirations and participation from the community (Adi 2013).

The selection of informants through purposive sampling namely managers and members of cooperative Pesantren as a 
community worker. Data were collected through interviews, focus group discussion, observation and analysis of the documentation. The research used a SWOT analysis, namely Strength, Weakness, Opportunity and Threats (Adisasmita 2006; Rangkuti 2006). This research was to analyze on how the strategy of cooperative Pesantrens in economic empowerment for Santri in El Bayan District of Cilacap, Central Java Province of Indonesia.

\section{Research Finding and Discussion}

Cooperative of Islamic Boarding School (Pesantren)

Cooperative of Pesantrens which place research at borading school of El Bayan dating from 1977 and developed into two foundation El Bayan 1 and El Bayan 2. Foundation El Bayan 1 located on the Padangjaya village, sub-district of Majenang, Cilacap District of Central Java Province which is about 10 kilometers from the location of the foundation El Bayan 2, known as the Komputama school located at Yos Sudarso street, number 36A sub-district of Majenang, District of Central Java Province. Foundation El Bayan 1 is a Pesantren that still maintains the tradition as a non formal education specifically for religious study. El Bayan 1 have Santri (Islamic Student) who stay and all the activities of life in Pesantren. Cooperative of El Bayan 1 built from passion to have a joint venture, fill in spare time, add to the experience, continue the efforts already initiated, but has not been professionally managed as stewardship are still limited, regeneration of the caretaker is not continuous (not periodic), management based on volunteerism and the appointment of the Chairman of the fundation.

Pesantren El Bayan 1 actually has the potential membership of all Santri numbering 700 people, but its nature is voluntary so it is not recorded in the formal administration and can not contribute capital to the cooperative. Capital and profit co-operative limited from business units that have been conducted namely stall unit small shop that provides the daily needs of Santri and the communities 
motorcycle repair business units, refill drinking water business unit, health clinics, Sewing services and a communal kitchen for catering celebration activities.

Institutional cooperatives have not supported by the policies of the Pesantren to become officially registered cooperatives and has legal entities, and lack the knowledge and the ability of Santri to manage cooperative professionally. Administrators of Pesantrens did not require the Santri become a member formally bound to increase capital, because Santri with disabilities funding. Pesantren has a principle of volunteerism (sincerity) in the process of religious education, i.e. non-commercial use and does not overload the students to pay the operational funds of the Pesantren. Pesantren while still maintaining its role as a religious institution and social agencies that help Santri as well as communities that are less able to get religious science in Pesantren.

The cooperative board still conduct meetings, but does not regularly each month, only carried out at least twice a year or when reporting the results of a business unit to the Pesantren menegement. The member meeting has not yet been implemented and does not have established regulations and cooperative work program. El Bayan has no centralized leadership managed by one parent or one Kiai (central leader), so that each unit of educational institution activities autonomously do their respective management. The implementation of businesses activities and cooperatives in Islamic society still has not been able to develop the economic sector of the people, because the availability of business opportunities that are available. Business facilities have not been given optimally, not yet perform the principle of efficiency and effectiveness, low capitalization, management weaknesses and limitations of implementing ability of the effort.

Syarbani (2012) stated, cooperative Pesantren assessed did not go forward with an indication of the low level of participation by students, not yet ready to face the global economic problems, 
limited management capabilities and management structures, limited capital and poor quality of human resources, less daring risks, low motivation and the dominant role of Kiai (The main leader). Community leaders at the mosque and Pesantrens had long been instrumental to society as an agent of change and a partner of the government in the economic empowerment of the people. So, if the community economically and morally can be supported by means of regulation and infrastructure, as well as the development policies of the government, then it is not happening again inequality of development that leads to uncontrolled urbanization with its negative effects (Thoha 2013).

There is the desire of the executive board of the Cooperative of El Bayan 1 to be able to join or cooperate with Cooperative of El Bayan 2 which already have legal entities and progressing. Cooperative of El Bayan 2 has a very advanced cooperatives especially the bank's business unit in the form called Baitul Mal Wattamwil (BMT) or micro bank with Islamic Shari'a. BMT is a micro finance institution that is using the principles of Islamic jurisprudence with profit sharing, and developing micro and small businesses to promote Islamic economy especially especially those in the weak economic category. The Foundation El Bayan 2 can be progress as supported by the formal institutions of the Islamic education and the national curriculum system i.e elementary school, junior high school and vocational high school of computer. So El Bayan 2 more professionally have the advantage due to the commercial use as private education institutions, while the El Bayan 1 is non formal educational institutions such as Pesantrens that are more social oriented or public-spirited.

Cooperative of El Bayan 1 and El Bayan 2 have a characteristic and unique that could complement and support each other, not as a competitor, because it have a considerable distance, social and economic differences, then potential and market share of different communities. El Bayan 1 is located in inland of village and has spacious land to develop agribusiness ventures unit such as 
agriculture, forestry, fishing and farms. The concept of agribusiness can open opportunities for business units to provide fertilizer, seeds, agricultural medicines and agricultural equipment. Cooperative of El Bayan 1 have a business unit that already active such as small shop, the motorcycle repair business units, refill drinking water business unit, health clinics, Sewing services and a communal kitchen for catering, it could be cooperate with Cooperative of El Bayan 2 in capital and marketing supprot.

Cooperative of El Bayan 2 more progress rapidly than Cooperative of El Bayan 1, in addition to implementing cooperative management professionally and it an official legal license. Cooperative of El Bayan 2 is supported by a strategic location in the urban areas and bypass the main roads in the highways of West Java and Central Java, it has micro bank with Islamic Shari'a called Baitul Mal Wattamwil (BMT), mini market, computer service and repair computer, and the motorcycle repair business units as well as much-needed by community. El Bayan 2 has formal education institutions especially vocational secondary school of computer are very supportive towards business unit of the cooperative, and insert the field of cooperatives and entrepreneurship in the education curriculum. According to Zaini (2014) the management Pesantrens forming the institutions of economic empowerment by researching and reviewing the needs of the Santri and the community. The next stages of the mentoring community organizes activities and establish cooperation with other parties (stakeholders) in the framework of the actualization of potential Pesantrens and the community.

However Cooperative of El Bayan 1 and Cooperative of El Bayan 2 have less able to cooperate to each other, because it is not in one management structure or in a separate management, it meaning El Bayan 2 is not under the institutional structure of El Bayan 1 vice versa. There is no agreement that can be accepted by both parties about distribution the benefits of El Bayan 2 that can be contributed to El Bayan 1 to assist in the development institutional of non-mandatory (voluntary) According to Anoraga 
and Widiyanti (2003) the cooperative is the common interest of its members in a family based on the works and services donated, its members as well as to avoid the conflict, mutual suspicion, the attitude of favoritism that creates division and destruction. Because the role of Pesantren according to Sham (2005) as religious and social institutions that serve to keep the values, morality, conflict resolution, and community empowerment.

Dialogue and tolerance are two absolute prerequisites for resolving conflicts with the two approaches, namely: the first formal ceremonial approach, and both the cultural approach. Formal ceremonial approach done by presenting a number of people from each group to agree with written proof of agreement statement. Second, the cultural approach to the informal or private nature in a family (Farid 2016).

Cooperative of El Bayan 1 which has the characteristic social and economic agriculture excellence in rural communities, could be developed into a cooperative agribusiness human resources supported in particular the Santri, who are lot and he lived at a Pesantren, so it has many opportunities to be utilized. Business units that already exist, can be developed namely small shop stalls, motor workshop, service recharge drinking water, health clinics and Sewing services. The potential at the El Bayan 1 can be supported and cooperated with the Cooperative of El Bayan 2 which has a characteristic in urban areas with microfinance cooperatives, a mini market and a computerized service. Cooperative of El Bayan 1 and Cooperative 2 can form a joint management to coordination and cooperation, so as to create the institutions of Islam with a modern boarding concept that combines the Pesantren education system (non-formal) with formal education using the national curriculum. Cooperatives are formed as a social and economic institutions that become the place of the Santri, then increase prosperity Pesantren, Santri and the community. The concept of a modern Pesantren cooperatives can be presented in Figure 1. 


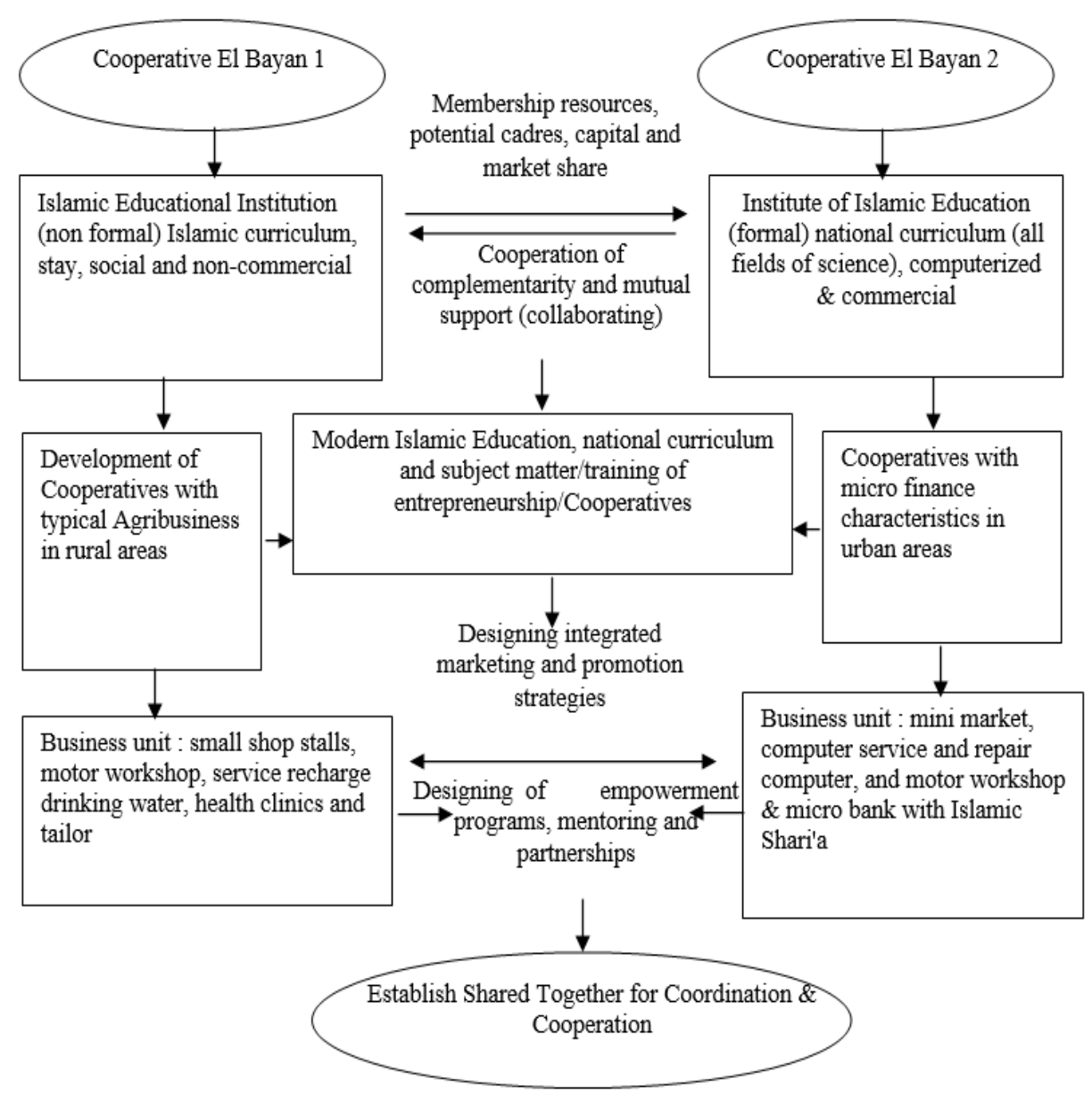

Figure 1.

\section{The Concept of Modern Cooperative Islamic Pesantren}

\section{Economic Empowerment Strategy for Santri}

Cooperative of El Bayan 1 still has barriers in managed ranging from stewardship, membership, institutional capital, which has not been legally incorporated, and a stagnant business units. So the Executive Board of the Foundation borading school should be support to develop and the empowerment potential of Santri 
and the community. It can also cooperate with other parties such as the local government and the university as well as Cooperative of El Bayan 2. The Cooperatives El Bayan 1 and El Bayan 2 have problems of miscommunication and impaired coordination, which is caused by disharmony. Therefore need to be resolved by way of a discussion between the administrators of the foundation with a principle mutual help, solidarity, and mutual benefit. Deliberations are conducted in an informal process of dialogue begins with personal figures and elders of both the foundation. The Other alternatives can be forming a team of mediation who accommodating aspirations of both parties for the scheduled meetings, and make the draft agreement based on the results of the identification and analysis of the aspirations of both parties. According to Sulaiman (2013) communication functions played by the actor of empowerment through participatory communication to planning, implement and evaluate development.

Cooperative of El Bayan 1 keep trying doing the process in cooperation with the Cooperative of El Bayan 2 and with other institutional parties. However, the cooperatives of El Bayan 1 should be able to independently conduct business development with all its potential. Administrators borading school should be supports both moral as well as material for developing cooperative and its business units, can open a dialog with Santri and administrators of the cooperative to identify and analyze problems, needs, potential and interest of Santri for empowerment program. The empowerment program aimed at development of boarding cooperative and business units, both capital, management, and marketing can be a medium of instruction, as well as the experience for Santri in entrepreneurship, provide additional income for Pesantren and Santri.

According to Fauroni (2013) Pesantren can build a business model based brotherhood (ukbuwah) and Pesantren as well as communities and economic ability with good welfare, and indicates the presence of a positive influence in the management of cooperative Pesantrens against the formation of entrepreneurial souls the Santri. 
The development of Cooperative El Bayan 1 in addition to organizing a cooperative managed empowerment and business units, it can also empower of students and community interests by utilizing the resources of Pesantren surroundings in the fields of agriculture, farms and fishery, which, so that the cooperative Pesantren of El Bayan 1 has the characteristic as a cooperative agribusiness involving the community. Because the Pesantren can not be separated from society, as according to Tilaar (2010) education Pesantrens is coming from the community and also managed by the community.

Cooperative of El Bayan 1 with implementing cooperation through the empowerment potential of Santri and the community, which supported managed cooperative professional Pesantren, so that creates continuity, economic prosperity and not making gaps between the Pesantren and the surrounding communities (Fasa 2014). Pesantren can be managed by the process of determining educational program and its evaluation by involving the community and graduate Santri to ask for input concerning the development of moral character and prosperity together (Muklasin 2016). Pesantren is very appropriate for carrying out the empowerment, because as a multifunctional institution in the field of education, religious, social and civic education process to have an unlimited amount of time, and still believed by people especially in rural areas (Zubaedi 2007).

Therefore, the Pesantren can provide additional learning subject matter like studying the concept of Shariah (Islamic) economics, entrepreneurship, economic cooperatives, and managed the Islamic economy. The multi-field learning can be deepened and practiced in the business unit in the cooperative's Pesantren, so Santri after graduating from Pesantren and returns to the public can work, opening businesses and make employment opportunities to improve welfare. The Pesantren can also enroll Santri and cooperative administrators, who are interested to follow the program of economic empowerment and cooperatives to other institutions such as local governments, universities, and non-governmental organizations. 
That matter to get the knowledge, experience, ability and network access can be beneficial to the progress of Santri, Pesantrens, cooperatives and communities. Tohani (2011) there is an education model softskill H-4 (head, heart, hands, and health) is very effective and beneficial for the development of a variety of life skills that should be possessed by the individual or the community. Model 4-H IE namely Head, is mean managing creativity and capability, Hands, working professionals and are able to give. Heart, establish relationships and communication. Health, the healthy physical and spiritual. So that the individual can cope with various life problems faced especially can overcome poverty. According to Syarbani (2012) positive change can be done Pesantren by combining the teaching of Islam and the economic empowerment of people as the centre of economic development of the Muslims in the local area in the form of Islamic financial institutions and cooperatives Pesantrens.

These changes in borading school are transforming the Salaf education system, who based on the purity of the teachings of Islam with education Khalaf, who uses general subject matter of social, economic, political and cultural, including the study of cooperatives and business units. According to Mahfud quoted Humaidi (2014) the Salaf borading school is affirmation the people who practicing Islam as practiced by the Prophet Mohammed, while Khalaf Pesantren have included public lessons and general subject matter in a modern and formal way.

In the context of this research is softskill subjects such as entrepreneurship and cooperatives as economic education for the Santri to improving welfare, including for Pesantren and community. Based on the results of research that To make the strategy in achieving the goal can use SWOT analysis (Suhartini 2012; Ayub et al; Maqbool et al. 2014). SWOT analysis consists of: (1) Internal factors which consist of Strength and Weakness. (2) External factors consists of Opportunity and Threats (Rangkuti 2006; Adisasmita 2006). Based on the SWOT analysis can be made Pesantren cooperative strategy as the economic empowerment of Santri as in table 1 
Table 1 SWOT Analysis and Strategy of Cooperative Boarding School in Economic Empowerment for Santri

\begin{tabular}{|c|c|c|}
\hline Int & $\begin{array}{l}\text { Strength (S) } \\
\text { 1. Santri as administrators of the } \\
\text { cooperative El Bayan } 1 \text { have the } \\
\text { passion and determination to develop } \\
\text { cooperative boarding school so that } \\
\text { law incorporated, add capital and } \\
\text { developing empowerment programs } \\
\text { business unit. } \\
\text { 2. Santri at El Bayan } 1 \text { are numerous, so } \\
\text { that potential to become members, } \\
\text { administrators and add capital to the } \\
\text { development of cooperative } \\
\text { 3. Boarding School of El Bayan } 1 \text { has a } \\
\text { vast land to be developed into a } \\
\text { cooperative business units such as } \\
\text { agriculture, forestry, fishery and } \\
\text { farm. } \\
\text { 4. Boarding cooperative of El Bayan } 1 \\
\text { have long existed and received the } \\
\text { community with business units, } \\
\text { which is able to meet the needs. }\end{array}$ & $\begin{array}{l}\text { Weakness (W) } \\
\text { 1. The boarding school of El Bayan } 1 \text { has } \\
\text { not managed cooperatives with } \\
\text { professional management for } \\
\text { stewardship, membership, } \\
\text { administration and capital or finance. } \\
\text { 2. The business unit in Cooperative El } \\
\text { Bayan } 1 \text { has not developed yet, just as } \\
\text { additional activities and only sufficient } \\
\text { daily needs. Not yet a business that can } \\
\text { train entrepreneurship and become } \\
\text { additional income for the welfare of } \\
\text { santri and boarding school } \\
\text { 3. Foundation of El Bayan } 1 \text { and } 2 \text { have } \\
\text { not been able to work together to } \\
\text { cooperate and support each other, } \\
\text { because it is still miscommunication } \\
\text { and lack of coordination between the } \\
\text { administrators and the structure of the } \\
\text { cooperative institutions is not at one } \\
\text { with administrative. }\end{array}$ \\
\hline $\begin{array}{l}\text { Opportunity (O) } \\
\text { 1. Boarding school of El Bayan } 1 \text { has a } \\
\text { vast land for the development of } \\
\text { cooperation with the business unit in } \\
\text { the field of Agriculture of rice, chicken } \\
\text { and duck farms, fishing and } \\
\text { plantations such as papaya and others. } \\
\text { 2. Students and the community at of El } \\
\text { Bayan } 1 \text { many potential to become a } \\
\text { member and administrator of the } \\
\text { cooperative for the development of } \\
\text { business units, capital and market } \\
\text { share } \\
\text { 3. Local governments, university and } \\
\text { Cooperative El Bayan } 2 \text { can be used as } \\
\text { partners to help the empowerment and } \\
\text { development of cooperatives and } \\
\text { business units }\end{array}$ & $\begin{array}{l}\text { 1. El Bayan Board } 1 \text { can make official } \\
\text { decisions or rules to support and } \\
\text { establish cooperatives with business } \\
\text { units as an activity that must be } \\
\text { followed by all Santri and open to the } \\
\text { community } \\
\text { 2. Boarding El Bayan } 1 \text { can invite or } \\
\text { have an audience with local } \\
\text { governments, colleges and El Bayan } \\
2 \text { to conduct field research and Santri } \\
\text { empowerment agriculture, forestry, } \\
\text { fishery and farm suitable interest \& } \\
\text { talent. } \\
\text { 3. The capital of the Santri and the } \\
\text { community as a member of the } \\
\text { cooperative can be used to the } \\
\text { development effort }\end{array}$ & $\begin{array}{l}\text { alumni and } \\
\text { members an } \\
\text { capital and by } \\
\text { expand mark } \\
\text { 2. Cooperati } \\
\text { forum dialog } \\
\text { the Cooperat } \\
\text { for mutual su } \\
\text { 3. The subje } \\
\text { entrepreneurs } \\
\text { agribusiness } \\
\text { curriculum in } \\
\text { gain expertis } \\
\text { to economic } \\
\text { being. }\end{array}$ \\
\hline $\begin{array}{l}\text { 1. The Boarding school and Santri in the } \\
\text { era of technological and economic } \\
\text { globalization in demand to be able to } \\
\text { answer the development of the era, } \\
\text { especially the problem of technology } \\
\text { adoption and economic welfare } \\
\text { 2. Islamic boarding school would be } \\
\text { undesirable if not adopting } \\
\text { technology \& economic development } \\
\text { 3. Unemployment is increasing, so } \\
\text { students must have the skills and work } \\
\text { experience in addition to about } \\
\text { religion } \\
\text { 4. There is still miscommunication and } \\
\text { lack of coordination between the } \\
\text { Cooperative El Bayan } 1 \text { and El Bayan } \\
2 \text { becomes the potential conflicts that } \\
\text { hinder the development of } \\
\text { cooperatives }\end{array}$ & $\begin{array}{l}\text { 1. Cooperative of El Bayan } 1 \text { can } \\
\text { organize computer training programs } \\
\text { for santri or carers who have interests } \\
\text { and talents especially about } \\
\text { managing administration, finance, } \\
\text { marketing and promotion such as } \\
\text { website management and social } \\
\text { media } \\
\text { 2. Record and expand the network of } \\
\text { boarding school alumni, cooperation } \\
\text { with local governments, university } \\
\text { and other boarding school through } \\
\text { social media technology facilities in } \\
\text { order to become a network, investor, } \\
\text { and marketing that help the } \\
\text { development of cooperatives as well } \\
\text { as product business unit. }\end{array}$ & $\begin{array}{l}\text { WT Strategy } \\
\text { 1.Computerized managed cooperatives } \\
\text { such as systems administration, } \\
\text { finance, marketing and promotional } \\
\text { 2. Cooperatives and business units have } \\
\text { websites and social media that can } \\
\text { promote and market their products to } \\
\text { the public. } \\
\text { 3. Santri are given subject metter and } \\
\text { computer practices that are included in } \\
\text { the additional curriculum at boarding } \\
\text { school to improve their administration, } \\
\text { finance, promotion and marketing } \\
\text { skills for entrepreneurship and } \\
\text { cooperatives. } \\
\text { 4. The Cooperatives of El Bayan } 1 \text { and El } \\
\text { Bayan } 2 \text { could making a joint } \\
\text { stewardship for mutually supportive } \\
\text { and profitable cooperation }\end{array}$ \\
\hline
\end{tabular}


Based on the SWOT analysis in table 1 it can be made a strategy of Pesantren in economic empowerment for Santri, which can be presented in Figure 1.

1.

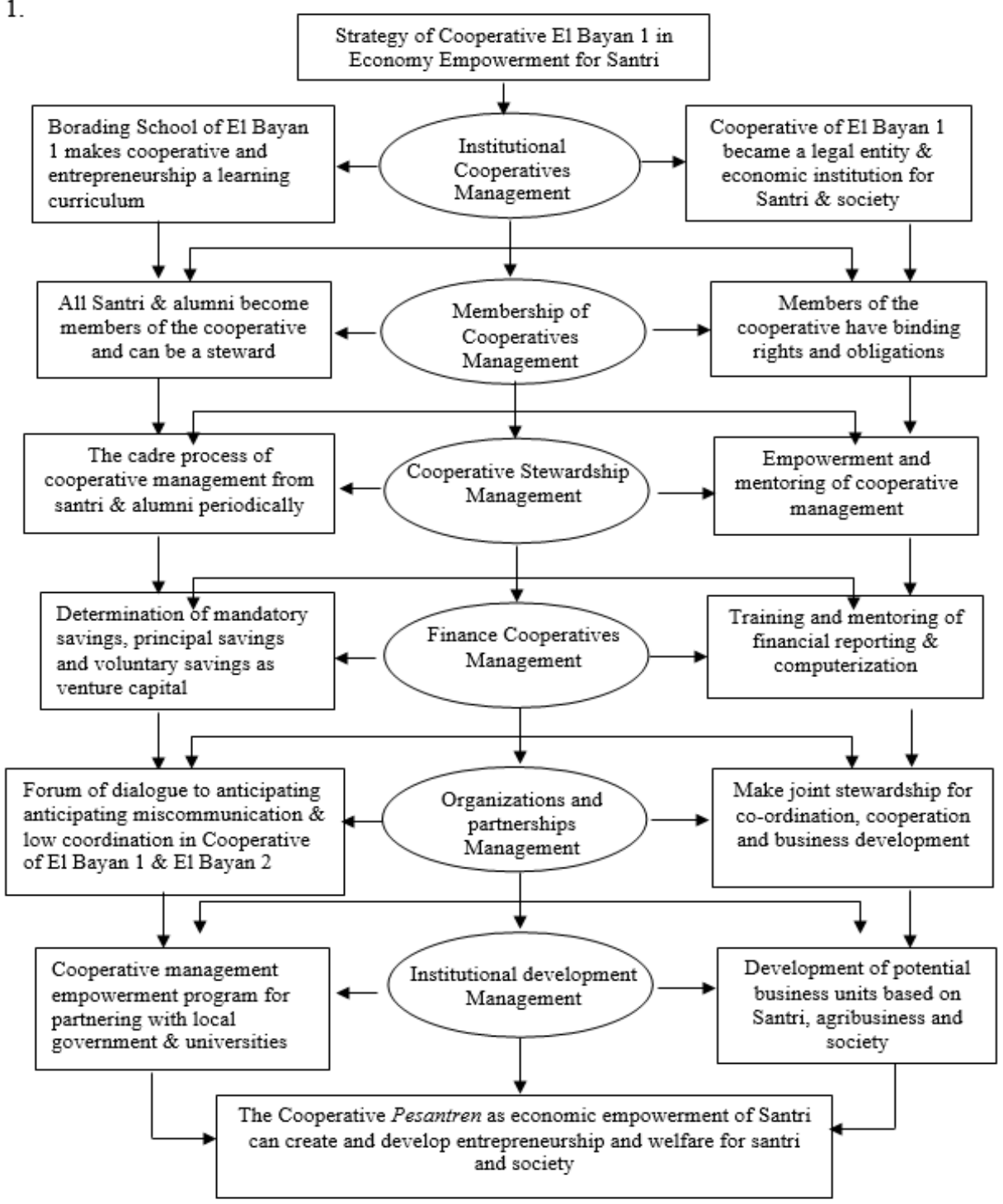

Figure 1.

\section{Strategy of Pesantren in economic empowerment for Santri}




\section{Conclusion}

Strategy of Cooperative of El Bayan 1 in economic empowerment can be implemented with: 1) Institutional management, Pesantren can formulate, establish and implement new curriculum program that charged about entrepreneurship and cooperatives. So that Santri can have the knowledge, motivation and experience in the field of economy as well as a very important additional income as provision, when graduating from Pesantren and socialize more with the community. Pesantren plan and supports the cooperative not only as media of learning and teaching entrepreneurship of Santri, but being economic institutions which incorporated the law in order to establish a partnership effort and capital good with local governments, universities, private parties or investors, as well as to financial services. 2) Membership management, Pesantren enrolling the Santri and alumni to become members of the cooperative, so there is informal and formal ties to participate and have a sense of belonging in advancing cooperative with its business unit, it will increase capital or investment. 3) Stewardship Management, Managed Pesantren set rules about the regeneration of the administrators cooperative in accordance with periodic interest and ability of Santri, so that the continued existence of the executive board. Any administrators and prospective administrators of the cooperative get counseling and training periodically about managed cooperatives and entrepreneurship, so that adds to the motivation, knowledge and skills. 4) Financial Management, this relates to the organizational membership and stewardship, it mean the better administrators manage and more members it will be a lot of capital income generating cooperatives for mandatory deposits, deposits from the principal and voluntary deposits, as well as administrators need to get the financial management training cooperation. 5) Organizations and partnerships Management, the create institutional cooperative relations of mutual support in the prosper all parties. The case can be made for coordination between the shared governance of the Cooperative of El Bayan 1 and El Bayan 2 as partners of mutual benefit. 6) Development Management, it can by proposing cooperation to the local government as the department of cooperatives and small and medium businesses as well as the 
Office of the economic empowerment of the community. Partnering with the university in a program teaching and the research and public service programs. Partnerships with other parties necessary to assist in cooperative empowerment and entrepreneurship ranging from counseling, coaching, and mentoring managed cooperatives and entrepreneurship, then expansion of marketing and access to capital. Development of business units as the goal of empowerment that could become potential cooperative as well as furthering the well-being of Pesantren, Santri and the community as a motor repair shop, small shop stall, refill drinking water, health clinics, sewing service and a communal kitchen. the other business development is agribusiness with rice farming, fish farm, papaya fruit plantation, chicken farm and duck.

These five aspects become important as a cooperative strategy for Pesantrens in economic empowerment for Santri and develop entrepreneurship as well as the welfare of Santri, Pesantren and the community.

\section{References}

Adi, I.S. 2013. Intervensi Komunitas dan Pengembangan Masyarakat : Sebagai Upaya Pemberdayaan Masyarakat. Jakarta: Rajawali Pers

Adisasmita, R. 2006. Membangun Desa Partisipatif. Yogyakarta : Graha Ilmu

Afadlal. Turmudi, Endang. \& Sihbudi, R (ed). 2005. Islam dan Radikalisme di Indonesia. Jakarta: LIPI Press

Ahyar, M. 2015. Membaca Gerakan Islam Radikal dan Deradikalisasi Gerakan Islam. Jurnal Walisongo. Vol. 23, No. 1: 1-26

Anoraga, P. \& Widiyanti, N. 2003. Dinamika Koperasi Jakarta : Rineka Cipta 
Ayub, A. Razzaq, A. Aslam, M.S \& Iftekhar, H. 2013. A Conceptual framework on evaluating SWOT analysis as the mediator in strategic marketing planning through marketing intelligence. European Journal of Business and Social Sciences. Vol. 2, No. 1: $91-98$

Farid, M. 2016. Dialog dan Toleransi Beragama di Kota Ambon: Perspektif Bekas Pejuang Muslim Ambon. International Journal of Islamic Thought. Vol. 9, No. 6: 44-50

Fasa, M.I. 2014. Manajemen Unit Usaha Koperasi: Studi Kasus Pondok Modern Darussalam Gontor 1 Ponorogo Jawa Timur. Tesis. Universitas Islam Negeri, Sunan Kalijaga Yogyakarta

Fauroni, L. 2013. Model Bisnis Berbasis Ukhuwah : Studi Kasus Pesantren Al-Ittifaq Kabupaten Bandung. Disertasi. Universitas Islam Negeri Sunan Kalijaga Yogyakarta

Hadi, AP. 1997. Jaringan Komunikasi Dalam Proses Difusi Teknologi Pengendalian Hama Terpadu di Kabupaten Lombok Timur. Jurnal Agroteksos. Vol. 7, No. 3: 1-7

Hidayat, K. 1998. Tragedi Raja Midas: Moralitas Agama dan Krisis Modernisme, Jakarta: Paramadina

Mahfud. 2014. Trasformasi Pendidikan Pondok Pesantren Hasan Jufri Sangkapura Bawean Gresik. Jurnal Didaktika Religi. Vol. 2, No. 1: 107-134

Maqbool, L., Ahmad, N., Hayyat, M.U., Mahmood, R. Haider, Z. \& Nawaz, R. 2014. Strengths, weaknesses, opportunities and threats (SWOT) analysis of environmental NGOs working in Punjab, Pakistan. International NGO Journal. Vol. 9, No.1: 11-16

Muklasin. 2016. Manajemen Pendidikan Karakter Santri: Studi Kualitatif di Pondok Pesantren Bahrul Ulum Margodadi Kecamatan Sumberejo Kabupaten Tanggamus. Tesis. Universitas Lampung

Rangkuti, F. 2006. Analisis SWOT: Teknik Membedah Kasus Bisnis. Jakarta: Gramedia 
Rizal, A.S. 2011. Transformasi Corak Edukasi dalam Sistem Pendidikan Pesantren dari Pola Tradisi ke Pola Modern. Jurnal Pendidikan Agama Islam -Ta'lim .Vol. 9 No. 2: 95-112

Sahakian,M.D., \& Dunan, C. 2014. The social and solidarity economy towards greater 'sustainability': learning across contexts and cultures, from Geneva to Manila. Community Development Journal. Vol. 50, No. 3: 403-417

Sham, F.Md., 2005. Tekanan Emosi Remaja Islam. Islamiyyat. Vol 27, No. 1:3-24

Stewart, R. 2015. Transition from Remote Indigenous Community to Pesantren: The Lockhart River Experience. UNESCO Observatory Multi-Disciplinary Journal in the Arts. Vol. 4, No. $1: 1-22$

Suhartini. 2012. Analisis SWOT dalam Menentukan Strategi Pemasaran pada Perusahan. Matrik. Vol. 12, No. 2: 1-7

Sulaiman, A.I. 2013. Model Komunikasi Formal Dan Informal Dalam Proses Kegiatan Pemberdayaan Masyarakat. Jurnal Penelitian Komunikasi. 16(2): 173-188

- Masrukin. Chusmeru. \& Pangestuti, S. 2016. Pemberdayaan Koperasi Pondok Pesantren sebagai Pendidikan Sosial dan Ekonomi Santri. Jurnal Pendidikan dan Pemberdayaan Masyarakat. 3 (2): 109-121

Susila, A.A. 2014. Strategi Kesuksesan Koperasi BMT Maslahah dalam Usaha dan Pemberdayaan Ekonomi Umat. Tesis. Universitas Islam Negeri Sunan Kalijaga Yogyakarta

Syamsi, B. 2013. Akulturasi Pesantren Jawa di Jambi. Kontekstualita. Vol. 28, No.1: 47-63

Syarbani, H. 2012. Analisis Pengaruh Partisipasi Santri Komitmen dan Kemampuan Berinovasi Terhadap Kinerja Koperasi Pondok Pesantren di Kota Semarang. Jurnal Economica. Vol. 2, No. 2: 27-42

Tan, C. 2014. Educative Tradition and Islamic Schools in Indonesia. Journal of Arabic and Islamic Studies. 14(1): 47-62 
Tattersall, A. 2015. The global spread of community organizing: how 'Alinsky-style' community organizing travelled to Australia and what we learnt?. Community Development Journal. Volume 50, Issue 3: 380-396

Thoha, M. 2013. Orientasi Santri dalam Menempuh Pendidikan Pesantren di Pamekasan. Jurnal Nuansa, Vol. 10. No. 1: 4970

Tohani, E. 2011. Pendidikan Nonformal dan Pengurangan Kemiskinan di Pedesaan. Jurnal Walisongo. Vol 19, No. 2:385-398

Tilaar, H.A.R. 2010. Membenahi Pendidikan Nasional. Jakarta: Rineka Cipta

Usman, MI. 2013. Pesantren Sebagai Lembaga Pendidikan Islam: Sejarah Lahir, Sistem Pendidikan dan Perkembangan Masa Kini. Jurnal Al Hikmah. 16(1): 101-119

Yuli, N.G., Haningsih, S., \& Adikrishna, R. 2011. The Common Room Design of Islamic Pesantren: A Preliminary Research in Yogyakarta Islamic Pesantren. International Journal of Engineering \& Technology. Vol. 11, No. 4: 127-134

Zaini, Muhammad. 2014. Strategi Pengembangan Pondok Pesantren Melalui Usaha Kecil Masyarakat. Jurnal Pendidikan Islam. Vol. 4 No.1: 175-199

Zubaedi. 2007. Pemberdayaan Masyarakat Berbasis Pesantren. Yogyakarta: Pustaka Pelajar 